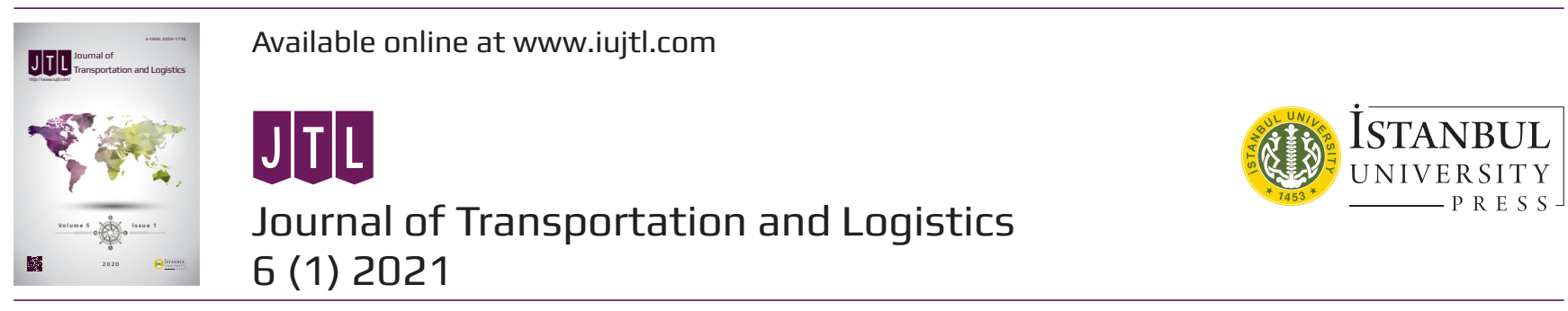

\title{
An Overview of Air Traffic and Effective Air Traffic Control Strategies for Istanbul Airport
}

\author{
Hava Trafiğine Genel Bir Bakıș ve İstanbul Havalimanı İçin Efektif Bir Hava Trafik \\ Kontrol Stratejisi
}

İsmail Demirhan ${ }^{1}$ (D), Abit Balin² (1), Abdullah Okumuș ${ }^{3}$ (1)

\begin{abstract}
This study addresses the significant changes in air transportation for Turkey with the opening of Istanbul Airport and investigates the advantages and disadvantages brought about by the new airport. Previously; providing a service for Istanbul, Atatürk Airport had a limited capacity in terms of air transportation resulting in a mostly ineffective use of time and resources. Thus; this study points out how Istanbul Airport solves the problems experienced previously problems with the expectations of being a solid contender for Turkey in today's modern aviation.

In this paper, a brief explanation of how aviation reached its current place is given and numerical data are provided to further clarify the enormous growth of civil aviation both for Turkey and globally. Subsequently, the role of Istanbul Airport for Turkish civil aviation has been explained in depth. In the light of this information, strengths and weaknesses are identified first, and then opportunities and weaknesses are presented (SWOT analysis) specifically for Istanbul Airport. In the final part of this paper, the importance of new applications through aviation systems has been evaluated briefly to better understand how it positively effects companies, air traffic control units and how it shapes the future of air transportation systems. We believe that the analysis given in four sub-sections will give us a clear understanding of the pros and cons of Istanbul Airport. Considering those assumptions and taking relevant actions it will be easier to make optimum use of the whole system in the airport and to compete with other rivals in the aviation industry.

Keywords: Intelligent Transport Systems, Aviation, Air Traffic Control, SWOT, Istanbul Airport
\end{abstract}

1 Corresponding author: İsmail Demirhan (Yüksek Lisans Öğrencisi), İstanbul Üniversitesi, Ulaştirma ve Lojistik Fakültesi, İstanbul, Türkiye E-mail: ismail.demirhan@ogr.iu.edu.tr ORCID: 0000-0001-7258-0719

2 Abit Balin (Dr. Öğr. Üyesi), İstanbul Üniversitesi, Ulaşttrma ve Lojistik Fakültesi, İstanbul, Türkiye. ORCID: 0000-0002-4590-2935

3 Abdullah Okumuş (Prof. Dr.), İstanbul Üniversite, İşletme Fakültesi - Pazarlama Anabilim Dalı, İstanbul, Türkiye. ORCID: 0000-0002-7556-384X

Citation: Demirhan, I., Balin, A., \& Okumus, A. (2021). Hava trafiğine genel bir bakış ve İstanbul havalimanı için efektif bir hava trafik kontrol stratejisi. Journal of Transportation and Logistics, 6(1), 107-124. https://doi.org/10.26650/JTL.2021.814387 


\section{Introduction}

Flying in the air has always captured human interest throughout the history. Even though it seemed like a utopia for the earliest civilizations, humankind has always kept hope alive to make this dream come true. The history of aviation extends back hundreds of years and the earliest forms such as kites were promising for future developments in the long run. From a tower jumping experience by Hezarfen Ahmet Celebi to futuristic designs of air vehicles drawn by Leonardo Da Vinci, every work and invention in aviation history provided a groundwork to be able to transport people through the air. Finally, the Wright Brothers were able to design the very first primitive aircraft by using previous works. Aviation has had a different vision and reached its current place with the effect of this invention (1).

People prioritize different factors such as speed, safety, comfort and cost for their transportation system choices and choose one of the four; road transport, maritime transport, rail transport or air transport. The ones who prioritize speed and comfort generally choose air transport. Hence the main reason why we choose air transportation of all the other methods is saving time as well as providing a joyful and comfortable travel. People are able to travel distances in a short period of time where they, otherwise, cannot do maybe in days or months (specifically for maritime transport). This summarizes why it becomes more and more popular among people day by day (2). Briefly, the aviation industry demonstrates an enormous development pattern affected by all of our choices and expectations. As a result; many procedures arise to provide a safe and controllable air traffic flow. Airports that are home to aircraft, airways, flying rules regarding piloting and air traffic control systems are all part of this well-sophisticated transportation system. By considering the needs of the time and sad events experienced in the past, aviation keeps its professional identity up to date through developmental activities. (3).

Despite being affected by certain events negatively; the aviation industry has historically shown a pattern of constant growth. Undoubtedly, this progress in the aviation industry requires building new facilities and upgrading technical infrastructure to meet the requirements of emerging industry. First opened in 1912 as a military airport, Atatürk Airport was converted into a civilian airport to serve passenger and cargo traffic in the early 1950s. It served more than 60 million passengers in 2015, making it one of the biggest airports in the world in terms of passenger traffic. Government authorities decided to replace Ataturk Airport with a new one with the hopes of building a groundwork for Turkey's future aviation strategies. Ataturk Airport was replaced in regards to commercial passenger functions by the newly constructed Istanbul Airport in April 2019, in order to meet Istanbul's growing domestic and international air traffic demand (4).

There is a two-way solution to providing safe and efficient air transportation; making the maximum use of current systems and/or construction. Legal authorities provided both in the case of Istanbul Airport with the intension of more competitiveness on a global scale. The objective of this paper is to search for changes and then to establish better strategies for Istanbul Airport with regard to air transportation. For these purposes we have examined capacity related problems and a variety of technical and technological 
issues that are of concern. Then, we introduced problem solving methods of how to efficiently provide air transportation with new facilities and with the introduction of new sub-systems. We believe that this study will establish a new perspective to gain a lead in the constantly growing sector.

This study was prepared under the supervision of two academicians. The liability of below given statements and other technical information was confirmed by legal aviation units; the air traffic control unit at Istanbul Airport and the Airport Authority; IGA. First, we confirmed the data accuracy (airport specifications and related functions) that we collected from varies databases by IGA operations center and DHMI. Then, the impact of Istanbul Airport in terms of air traffic management was evaluated by air traffic controllers - a supervisor with 20-years of job experience and two veteran air traffic controllers with 5 and 11 years of job experience respectively. Finally, the assumptions we made were discussed by academicians that had studies in the transportation and logistics field- a professor with over 20 years of experience and a lecturer with over 10 years of experience.

This paper consists of six subsections; following a quick introductory division about the history of aviation, a variety of different studies have been listed in the second division. In the third section, a table analysis regarding air transportation in the World and in Turkey has been presented. The forth section provides in depth information about Istanbul Airport and a SWOT analysis for the airport. The fifth section is based on air traffic control strategies deducted by SWOT analysis given in the previous section. Finally, the sixth section concludes this study demonstrating, from a more general perspective, how this study is important for the future of the Turkish aviation industry.

\section{Literature Review}

There has been a lot of academic studies as well as technical work in air transportation to meet today's needs of the sector and to better plan the future of it. Some of the important studies chosen for the purpose of this paper are listed in table-1

Table 1. Literature review on aviation

\begin{tabular}{|c|c|c|c|c|}
\hline & PAPER WORK & AUTHORS & METHODOLOGY & CONCEPT \\
\hline 1 & $\begin{array}{l}\text { Uçakların Terminal Kapılarına Atanması } \\
\text { Probleminin Farklı Yöntemlerle Çözümü } \\
\text { ve Uygulaması (2011) }\end{array}$ & Şefika ARSLAN & Optimization & $\begin{array}{l}\text { Effective utilization of } \\
\text { terminal gates }\end{array}$ \\
\hline 2 & $\begin{array}{l}\text { Bulamık Mantık Kontrol Tekniği } \\
\text { Kullanarak Pist Planlama İçin Uçak Tipine } \\
\text { Göre İniş Önceliklendirme (2019) }\end{array}$ & Tolga ÇALLIOĞLU & Fuzzy Approach & $\begin{array}{l}\text { Answers for better aircraft } \\
\text { landing sequences }\end{array}$ \\
\hline 3 & $\begin{array}{l}\text { Aircraft Parking Optimization Using } \\
\text { Genetic Algorithm (2017) }\end{array}$ & Burak GÜLER & Optimization & $\begin{array}{l}\text { Effective usage of the } \\
\text { parking positions }\end{array}$ \\
\hline 4 & $\begin{array}{l}\text { On-line Decision Support for Take-off } \\
\text { Runway Scheduling at London Heathrow } \\
\text { Airport (2008) }\end{array}$ & $\begin{array}{l}\text { Jason Adam David } \\
\text { ATKIN }\end{array}$ & Optimization and Simulation & Runway scheduling \\
\hline 5 & $\begin{array}{l}\text { On The Control of Airport Departure } \\
\text { Operations (2010) }\end{array}$ & Pierrick BURGAIN & Collaborative framework & $\begin{array}{l}\text { The control of aircraft } \\
\text { operations }\end{array}$ \\
\hline
\end{tabular}




\begin{tabular}{|c|c|c|c|c|}
\hline 6 & $\begin{array}{l}\text { Conflict Distribution Prediction and } \\
\text { Optimization of Aircraft in Ground } \\
\text { Movements (2020) }\end{array}$ & $\begin{array}{l}\text { Yassine } \\
\text { DABACHINE, } \\
\text { Mohamed BINIZ, } \\
\text { Belaid } \\
\text { BOUIKHALENE, } \\
\text { Abdessamad } \\
\text { BALOUKI (2020) }\end{array}$ & Optimization & $\begin{array}{l}\text { Ground movement control } \\
\text { (taxi movement) }\end{array}$ \\
\hline 7 & $\begin{array}{l}\text { Models of Air Traffic Merging Techniques: } \\
\text { Evaluating Performance of Point Merge } \\
(2009)\end{array}$ & $\begin{array}{l}\text { Dan IVANESCU, } \\
\text { Chris SHAW, } \\
\text { Constantine } \\
\text { TAMVACLIS, Tarja } \\
\text { KETTUNEN }\end{array}$ & Merge point system & $\begin{array}{l}\text { Performance analysis of } \\
\text { the system }\end{array}$ \\
\hline 8 & $\begin{array}{l}\text { Taxiing Route Scheduling between } \\
\text { Taxiway and Runway in Hub Airport } \\
(2015)\end{array}$ & $\begin{array}{l}\text { Yu JIANG } \\
\text { Xinxing XU } \\
\text { Honghai ZHANG } \\
\text { Yuxiao LUO }\end{array}$ & Optimization & $\begin{array}{l}\text { Ground movement control } \\
\text { of an aircraft }\end{array}$ \\
\hline 9 & $\begin{array}{l}\text { An Optimization Framework For Route } \\
\text { Design and Allocation of Aircraft to } \\
\text { Multiple Departure Routes (2019) }\end{array}$ & $\begin{array}{l}\text { V. HO-HUU, } \\
\text { S. HARTJES, } \\
\text { H. G. VISSER, } \\
\text { R. CURREN }\end{array}$ & Optimization & $\begin{array}{l}\text { Analyzing and optimizing } \\
\text { departure routes }\end{array}$ \\
\hline 10 & $\begin{array}{l}\text { Multirunway Optimization Schedule } \\
\text { of Airport Based on Improved Genetic } \\
\text { Algorithm by Dynamical Time Window } \\
\text { (2015) }\end{array}$ & $\begin{array}{l}\text { Hang ZHOU, } \\
\text { Xinxin JIANG }\end{array}$ & Optimization & $\begin{array}{l}\text { Optimizing multi runway } \\
\text { airport movements }\end{array}$ \\
\hline 11 & $\begin{array}{l}\text { ICAO Uçak Kategorilerine Göre Tek Pist } \\
\text { Sistemi İçin Kapasite Hesaplamalarında } \\
\text { Kullanılacak Analitik Bir Model (2013) }\end{array}$ & Serkan BAYAR & Technical analysis & $\begin{array}{l}\text { Analyzing runway } \\
\text { capacity }\end{array}$ \\
\hline 12 & $\begin{array}{l}\text { Strategical Analysis and the Impact of } \\
\text { Istanbul Airport on Turkish Airlines (2020) }\end{array}$ & $\begin{array}{l}\text { Muhammet } \\
\text { DEVECI, Muharrem } \\
\text { Enis ÇIFTÇİ, } \\
\text { İbrahim Zeki } \\
\text { AKYURT }\end{array}$ & SWOT analysis & $\begin{array}{l}\text { The impact of İstanbul } \\
\text { Airport on Turkish } \\
\text { Airlines }\end{array}$ \\
\hline 13 & $\begin{array}{l}\text { System Analysis of Airport Capacity } \\
\text { and Slot Coordination at Ataturk Airport } \\
(2016)\end{array}$ & $\begin{array}{l}\text { Savaş S. ATEŞ, } \\
\text { Mevlüt ÜZÜLMEZ }\end{array}$ & System analysis & $\begin{array}{l}\text { The assessment of slot } \\
\text { coordination system used } \\
\text { at Ataturk Airport }\end{array}$ \\
\hline 14 & $\begin{array}{l}\text { Kentsel Lojistik Açısından İstanbul } \\
\text { Havalimanı ve Ataturk Havalimanı’nın } \\
\text { Değerlendirilmesi (2019) }\end{array}$ & $\begin{array}{l}\text { Doğan KILIÇ, } \\
\text { Muhammet } \\
\text { TURGUT }\end{array}$ & System comparison & $\begin{array}{l}\text { A comparison of two } \\
\text { airports in terms of urban } \\
\text { logistics and capacity }\end{array}$ \\
\hline 15 & $\begin{array}{l}\text { The Economic \& Social Benefits of Air } \\
\text { Transport (2004) }\end{array}$ & $\begin{array}{l}\text { Air Transport Action } \\
\text { Group (ATAG) }\end{array}$ & System analysis & $\begin{array}{l}\text { An analysis of air } \\
\text { transport systems }\end{array}$ \\
\hline 16 & $\begin{array}{l}\text { Solving Aircraft Routing Problem with } \\
\text { Integer Programming (2009) }\end{array}$ & Nahit KİRAZOĞLU & Optimization & $\begin{array}{l}\text { Optimality of flight path } \\
\text { among cities }\end{array}$ \\
\hline 17 & Airport Runway Optimization (2012) & $\begin{array}{l}\text { Mohammad } \\
\text { MESGARPOUR }\end{array}$ & Optimization & $\begin{array}{l}\text { Scheduling of aircraft } \\
\text { landing and take-off } \\
\text { problems on a single } \\
\text { runway }\end{array}$ \\
\hline 18 & $\begin{array}{l}\text { Empirical Investigations of Properties of } \\
\text { Robust Aircraft Routing Models (2015) }\end{array}$ & Guanqun LI & Routing & Aircraft routing problem \\
\hline 19 & $\begin{array}{l}\text { Enhancing Decision Support Systems for } \\
\text { Airport Ground Movement (2013) }\end{array}$ & Stefan RAVIZZA & Optimization & $\begin{array}{l}\text { Models and algorithms } \\
\text { for aircraft ground } \\
\text { movement }\end{array}$ \\
\hline 20 & $\begin{array}{l}\text { Integration of Automated Decision Aids } \\
\text { with a Prototype Air Traffic Control } \\
\text { Interface in Support of Time-Based } \\
\text { Surface Operations (2012) }\end{array}$ & Kenyon T. RIDDLE & Simulation & $\begin{array}{l}\text { Sequencing departure } \\
\text { aircraft at the gate }\end{array}$ \\
\hline 21 & $\begin{array}{l}\text { Modelling of Ground Operations Using } \\
\text { End-Around (Perimeter) Taxiways fot the } \\
\text { Modernized Chicago O'Hare International } \\
\text { Airport (2013) }\end{array}$ & $\begin{array}{l}\text { Ashwin Vasant } \\
\text { JADHAV }\end{array}$ & Simulation & $\begin{array}{l}\text { The impact of airport } \\
\text { layout modifications }\end{array}$ \\
\hline
\end{tabular}


The above-mentioned studies focus on making air traffic management more effective, using all the available sources more efficiently and searching for ways to solve any other problems experienced in aviation sub-systems.

\section{Air Traffic Analysis}

When we think of aviation, the first vehicles that come to mind are airplanes and helicopters as well as balloons as one of the earliest forms of aviation and drones as more recent developments (5). Nevertheless, aircraft such as airplanes, business jets and helicopters are the basis of this study considering the regular air traffic at an airport.

In a little over a century, the aviation industry has gone from learning to fly, to learning to fly faster and further. Moreover, air transportation has become widely used and continues to extend its reach through rising incomes and affordable choices. The volume of air transportation is not surprising to us anymore since the industry has been expanding.

We keep track of air transportation by annual reviews. Annual reviews for air transportation are released by certain organizations on the successes, issues and numerical changes. Those reports reveal how big the aviation industry is. In figure 1, we give a demonstration of air transportation statistics regarding passenger traffic, air cargo and aircraft movements by region.

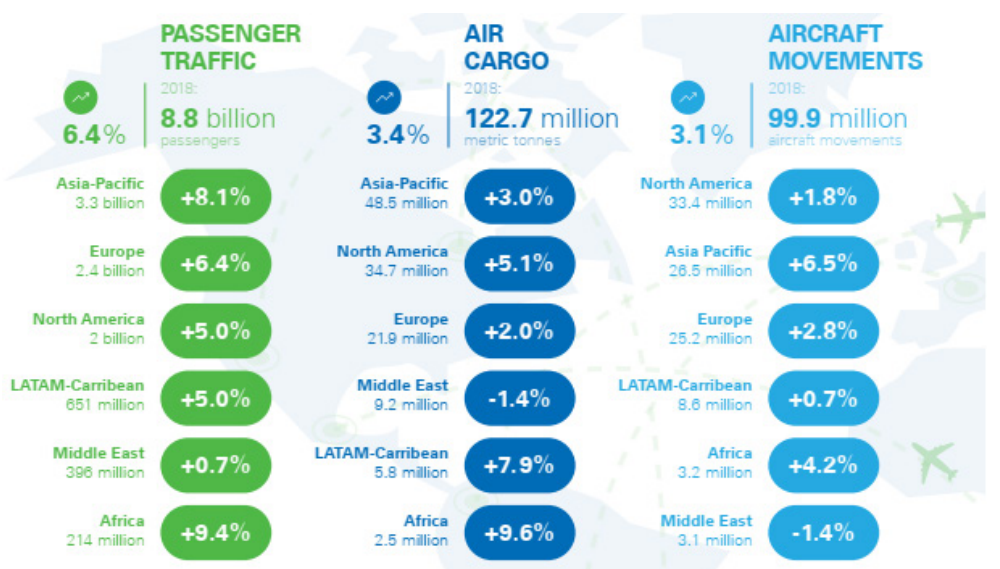

Figure 1. Annual report of passenger traffic, air cargo and aircraft movement in 2018 by Airports Council International-ACI (6).

Airports host millions of passengers to provide service in air transportation. Considering major airports specifically, those numbers require hundreds of flights each day. In table-2, we show the top airports per landing and take-off in 2010 and in 2017. Taking $16^{\text {th }}$ position in 2017, Istanbul Ataturk Airport proved to be one of the fastest growing airports in the world. This growing rate also took an important role in building a new and modern airport - Istanbul Airport. 
Table 2. Top airports in 2010 and in 2017 per landing and takeoff (7)

\begin{tabular}{|l|l|l|l|l|l|}
\hline $\mathbf{2 0 1 0}$ & \multicolumn{5}{|l|}{$\mathbf{2 0 1 7}$} \\
\hline RANK & CITY (AIRPORT) & $\begin{array}{l}\text { TOTAL } \\
\text { MOVEMENTS }\end{array}$ & RANK & CITY (AIRPORT) & $\begin{array}{l}\text { TOTAL } \\
\text { MOVEMENTS }\end{array}$ \\
\hline $\mathbf{1}$ & ATLANTA - ATL & 950119 & $\mathbf{1}$ & ATLANTA - ATL & 879560 \\
\hline $\mathbf{2}$ & CHICAGO - ORD & 882617 & $\mathbf{2}$ & CHICAGO - ORD & 867049 \\
\hline $\mathbf{3}$ & LOS ANGELES - LAX & 666938 & $\mathbf{3}$ & LOS ANGELES - LAX & 700362 \\
\hline $\mathbf{4}$ & DALLAS - DFW & 652261 & $\mathbf{4}$ & DALLAS - DFW & 654344 \\
\hline $\mathbf{5}$ & DENVER - DEN & 630063 & $\mathbf{5}$ & BEIJING - PEK & 597259 \\
\hline $\mathbf{6}$ & HOUSTON - IAH & 531347 & $\mathbf{6}$ & DENVER - DEN & 574966 \\
\hline $\mathbf{7}$ & CHARLOTTE - CLT & 529101 & $\mathbf{7}$ & CHARLOTTE - CLT & 553817 \\
\hline $\mathbf{8}$ & BEIJING - PEK & 517584 & $\mathbf{8}$ & LAS VEGAS - LAS & 542994 \\
\hline $\mathbf{9}$ & LAS VEGAS - LAS & 505591 & $\mathbf{9}$ & AMSTERDAM - AMS & 514625 \\
\hline $\mathbf{1 0}$ & PARIS - CDG & 499997 & $\mathbf{1 0}$ & SHANGHAI - PVG & 496774 \\
\hline $\mathbf{1 1}$ & FRANKFURT - FRA & 464432 & $\mathbf{1 1}$ & PARIS - CDG & 482676 \\
\hline $\mathbf{1 2}$ & PHILADELPHIA - PHL & 460799 & $\mathbf{1 2}$ & LONDON - LHR & 475915 \\
\hline $\mathbf{1 3}$ & LONDON LHR & 454883 & $\mathbf{1 3}$ & FRANKFURT - FRA & 475537 \\
\hline $\mathbf{1 4}$ & DETROIT - DTW & 452616 & $\mathbf{1 4}$ & TORONTO - YYZ & 465555 \\
\hline $\mathbf{1 5}$ & PHOENIX - PHX & 449351 & $\mathbf{1 5}$ & GUANGZHOU - CAN & 465295 \\
\hline $\mathbf{1 6}$ & MINNEAPOLIS - MSP & 436625 & $\mathbf{1 6}$ & ISTANBUL - IST & 460785 \\
\hline $\mathbf{1 7}$ & MADRID - MAD & 433683 & $\mathbf{1 7}$ & SAN FRANCISCO - SFO & 460243 \\
\hline $\mathbf{1 8}$ & TORONTO - YYZ & 418298 & $\mathbf{1 8}$ & TOKYO - HND & 453126 \\
\hline $\mathbf{1 9}$ & NEWARK - EWR & 403880 & $\mathbf{1 9}$ & HOUSTON - IAH & 450383 \\
\hline $\mathbf{2 0}$ & AMSTERDAM - AMS & 402372 & $\mathbf{2 0}$ & MEXICO CITY - MEX & 449664 \\
\hline
\end{tabular}

Table 3. The change in passenger and aircraft traffic for Turkey through 2010 - 2019 (10).

\begin{tabular}{|c|c|c|c|c|c|c|}
\hline \multirow{2}{*}{ Year } & \multicolumn{3}{|c|}{ Passenger Traffic } & \multicolumn{3}{|c|}{ Aircraft Traffic } \\
\hline & Domestic & International & Transit & Domestic & International & Transit \\
\hline \multirow[t]{2}{*}{2010} & 50575426 & 52224966 & 736121 & 497862 & 421549 & 293714 \\
\hline & \multicolumn{3}{|c|}{ Total: 103536513} & \multicolumn{3}{|c|}{ Total: 1213125} \\
\hline \multirow[t]{2}{*}{2011} & 58258324 & 59362145 & 671531 & 579488 & 462881 & 292816 \\
\hline & \multicolumn{3}{|c|}{ Total: 118292000} & \multicolumn{3}{|c|}{ Total:1 335185} \\
\hline \multirow[t]{2}{*}{2012} & 64721316 & 65630304 & 677896 & 600818 & 492229 & 283439 \\
\hline & \multicolumn{3}{|c|}{ Total: 131029516} & \multicolumn{3}{|c|}{ Total: 1376486} \\
\hline \multirow[t]{2}{*}{2013} & 76148526 & 73281895 & 565447 & 682685 & 541110 & 281178 \\
\hline & \multicolumn{3}{|c|}{ Total: 149995868} & \multicolumn{3}{|c|}{ Total: 1504973} \\
\hline \multirow[t]{2}{*}{2014} & 85416166 & 80304068 & 461105 & 754259 & 591695 & 333017 \\
\hline & \multicolumn{3}{|c|}{ Total: 166181339} & \multicolumn{3}{|c|}{ Total: 1678971} \\
\hline \multirow[t]{2}{*}{2015} & 97041210 & 84033321 & 362473 & 832958 & 623715 & 358285 \\
\hline & \multicolumn{3}{|c|}{ Total: 181437004} & \multicolumn{3}{|c|}{ Total: 1814958} \\
\hline \multirow[t]{2}{*}{2016} & 102499358 & 71244179 & 409609 & 886228 & 566767 & 376913 \\
\hline & \multicolumn{3}{|c|}{ Total: 174153146} & \multicolumn{3}{|c|}{ Total: 1829908} \\
\hline \multirow[t]{2}{*}{2017} & 109511390 & 83533953 & 531501 & 909332 & 591125 & 413560 \\
\hline & \multicolumn{3}{|c|}{ Total: 193576844} & \multicolumn{3}{|c|}{ Total: 1914017} \\
\hline \multirow[t]{2}{*}{2018} & 112911108 & 97587056 & 449475 & 892405 & 651764 & 473051 \\
\hline & \multicolumn{3}{|c|}{ Total: 210947639} & \multicolumn{3}{|c|}{ Total: 2017220} \\
\hline \multirow[t]{2}{*}{2019} & 99946572 & 108427124 & 537642 & 839894 & 716523 & 478013 \\
\hline & \multicolumn{3}{|c|}{ Total: 208911338} & \multicolumn{3}{|c|}{ Total: 2034430} \\
\hline
\end{tabular}


Air transportation keeps a development pattern even though it is affected by occasional crisis like the most current one; the Covid-19 pandemic (8). While aviation keeps developing all around the world, the same growth is seen for Turkey. The General Directorate of State Airports (DHMI) is the authority that is responsible for the management and regulation of airports, aerodromes and airspace under Turkish responsibility (9). The reports by DHMI released on a monthly and yearly basis is also a clear indication of a growth in air transportation for Turkey. Table-3 summarizes the change in passenger and aircraft traffic for Turkey through the years 2010-2019.

In Figure 2 and 3, we represent the graphic form of table 2 in order to visualize the changes throughout the years.

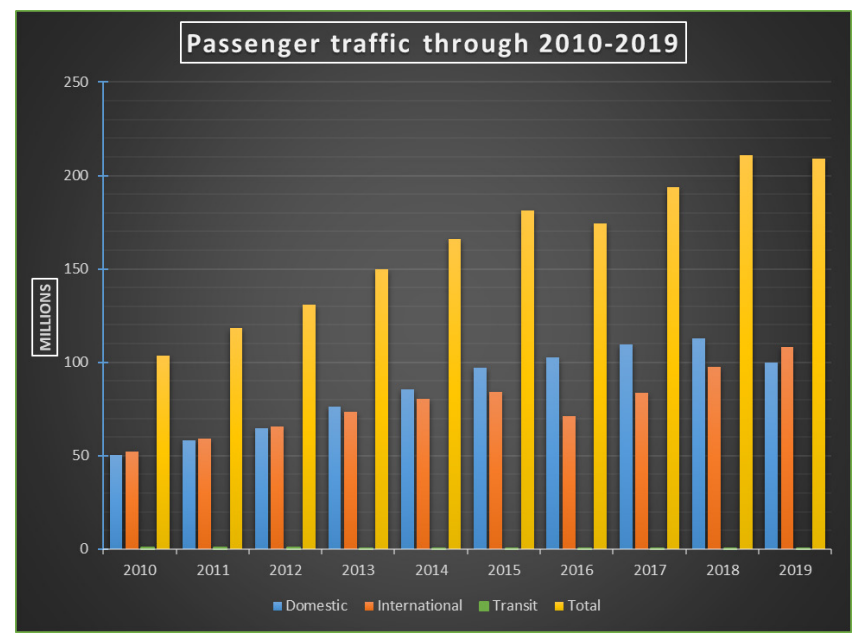

Figure 2. The change in passenger traffic for Turkey through 2010-2019

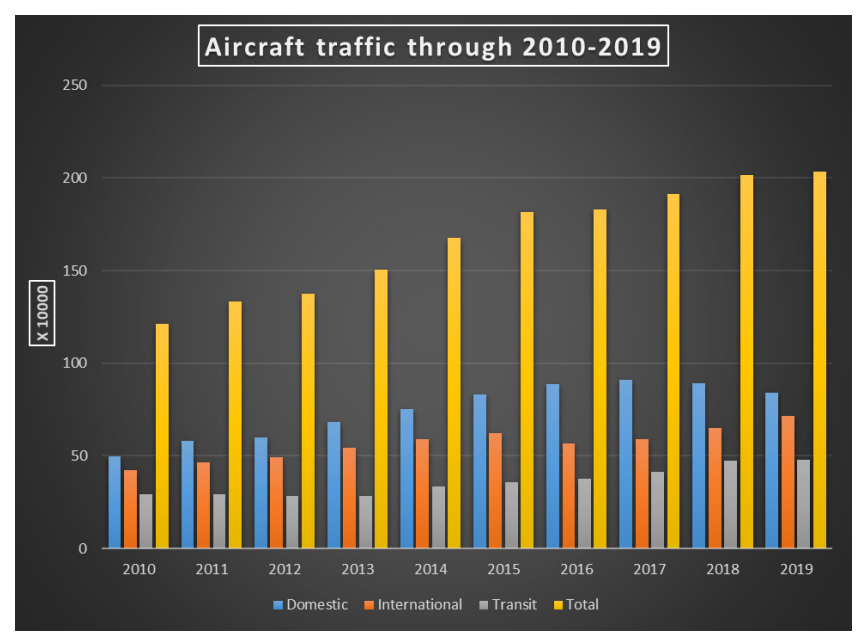

Figure 3. The change in aircraft traffic for Turkey through 2010-2019

In table 4, we specifically compare the numbers in the years 2018 and 2019. The number of domestic and international flights in total are presented for Turkey; both for state airport (DHMI) and for other civilian airports. Looking at table-3, a dramatic decrease $(25,14 \%)$ can be seen in air traffic for the state airports while there is a considerable amount of increase in total. This is because Atatürk Airport, also the busiest airport in Turkey, that was run by the DHMI until early 2019 was closed to passenger traffic and 
Istanbul Airport that has been run by a private organization (IGA), took its place. The number of en route traffic showed a growth rate by 1.04 . The total air traffic numbers increased slightly, by $0.85 \%$, that means a continuation of development figure in 2019 considering the year before.

Table 4. Air traffic data for Tukey in 2018 and 2019 (10)

\begin{tabular}{|l|c|c|c|c|c|c|}
\hline & \multicolumn{3}{|c|}{2018} & \multicolumn{3}{c|}{2019} \\
\hline & Domestic & International & Total & Domestic & International & Total \\
\hline DHMI & 716,407 & 559,287 & $1,275,694$ & 591,205 & 363,739 & 954,944 \\
\hline General & 892,405 & 651,764 & $1,544,169$ & 839,894 & 716,523 & $1,556,417$ \\
\hline En route & & & 473,051 & & & 478,013 \\
\hline Turkey & & & $2,017,220$ & & & $2,034,430$ \\
\hline
\end{tabular}

Air transportation, for which some of the numerical data is given, holds many different advantages and disadvantages to it as a result of a constantly growing industry. While the upward trend in the number of passengers and air traffic continues, the achievements by air transportation shows promising results. With this in mind, investments are crucial to accommodate aviation growth. Recent investments over aviation in Turkey brought about significant changes that will put the country in an important position in the world. Those investments, as well as technological developments, offer noteworthy opportunities in the long term. Specifically, Istanbul Airport; one of the mega projects of Turkey in aviation, is a representation of a great vision of the country. At this point, the opening of the airport stage by stage has led to a new growth acceleration in Turkish aviation. In table- 6 below, a SWOT analysis about air transportation has been presented for Istanbul Airport.

\section{SWOT analysis on Istanbul Airport}

\subsection{Strengths of Istanbul Airport}

\section{Additional runway capacity}

Ataturk Airport was famous for long departure queues specifically during rush hours. Aircraft would spend a lot of time waiting for their departure sequence in line. Istanbul Airport relieves this bottleneck with the help of an increased capacity through additional runways.

At present, Istanbul Airport has 3 parallel runways in use. There will be six of those when all the phases are completed, making the airport one of the few in the world in this category. Runway 34 (2 dependent runways-34 R/L), runway 35 (2 dependent runways-35 R/L) and runway 36 have been used for arrivals and departures as of June 2020 (11). Independent runways can be used for parallel arrival/departure operations simultaneously. This procedure helps improve the air traffic capacity with the reduction of aircraft waiting time. 


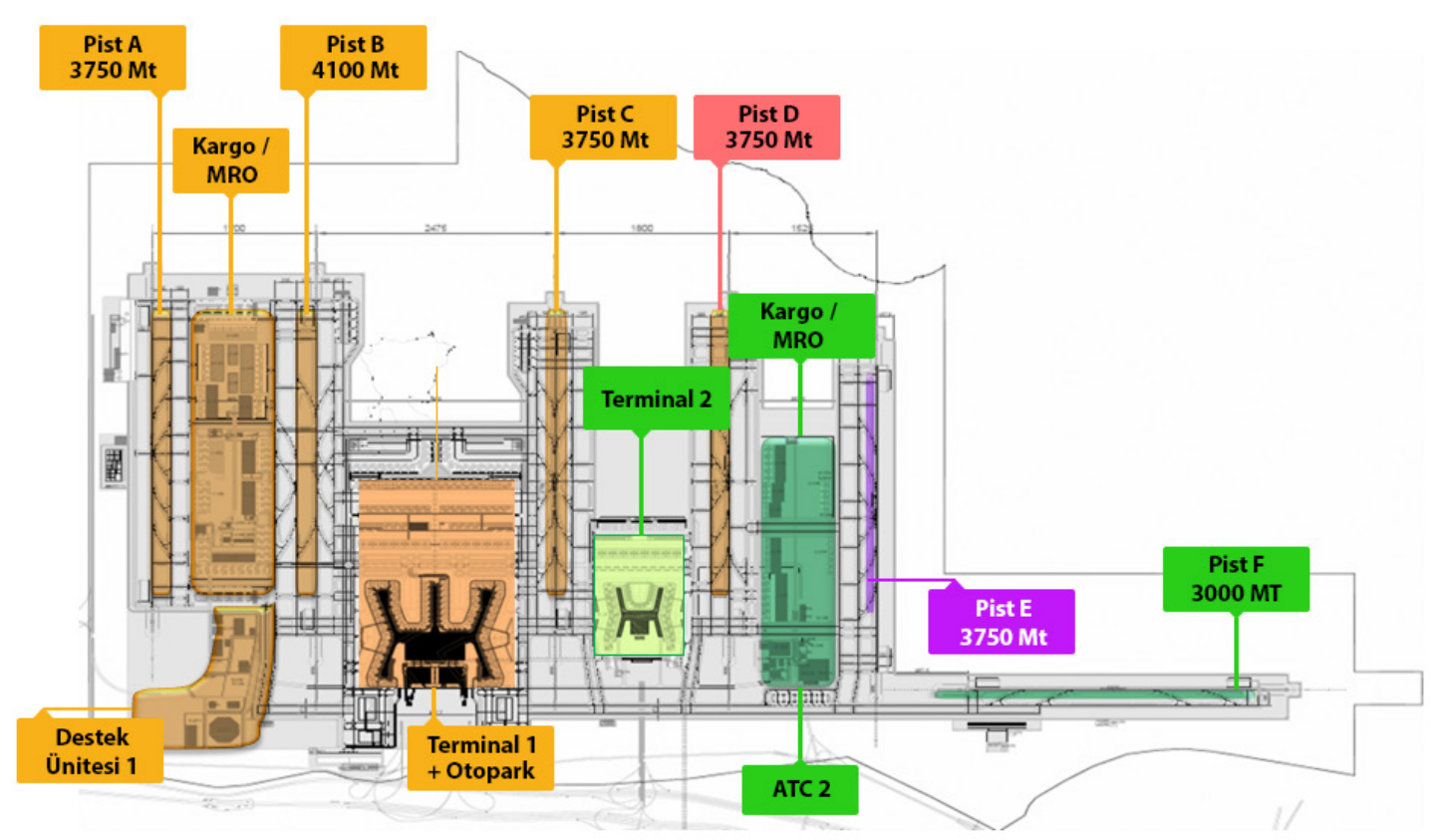

Figure 4. All phases planned for Istanbul Airport (12)

\section{Merge Point system}

A point merge system, a systemized method for sequencing arrival flows developed by the Eurocontrol Experimental Centre, is implemented at İstanbul Airport as an arrival procedure. This system was designed to work in high traffic loads without radar vectoring. It consists of a point (so-called merge point) and pre-defined legs (the sequencing legs) equidistant from this point. The legs are only used to delay aircraft when necessary. Some of the expected benefits of point merge are as follows; more orderly flows of air traffic, the standardization of operations, better airspace management, improved flight efficiency etc. (13).
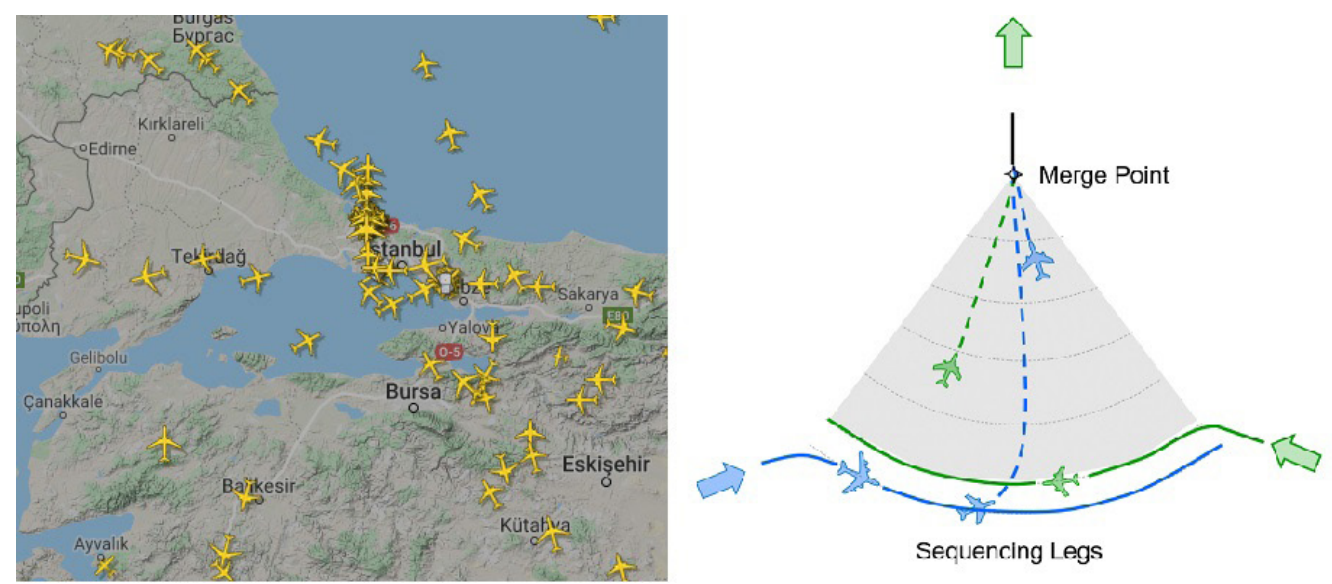

Figure 5. A congested airspace over the Marmara Region can be seen on the left, and a merge point system as a possible solution 


\section{Increased aircraft capacity}

The apron area has 77 jet bridges (this number can go up to 114 for category - C aircraft), 157 open parking positions (this number can go up to 226 for category - C aircraft). Briefly, the terminal area has an extended parking capacity compared to Atatürk Airport; 234 parking positions in total and this number can also go up to 340 for category - C aircraft (14).

Table 5. Some of the important specifications of Istanbul Airport (15)

\begin{tabular}{|l|l|}
\hline Specification & Capacity \\
\hline Runways & 5 runways currently \\
\hline Passenger boarding bridges & 143 \\
\hline Passenger capacity & A full capacity of 200 million \\
\hline Terminals & 4 terminal buildings $(1,3$ square meter main terminal building $)$ \\
\hline Apron & A full capacity of 500 aircraft \\
\hline Parking area & Up to 70.000 indoor and outdoor parking lot \\
\hline Destinations & Over 350 flight destinations \\
\hline Taxiway Link & 16 taxiways in total, some eligible for code-F aircraft (A380, B748) \\
\hline
\end{tabular}

\section{The design to accommodate super-heavy aircraft}

Runways and taxiways were designed so that companies are able to make operations with any kind of aircraft. In particular, A380 and B748 (super-heavy category aircraft) can fly from/to Istanbul Airport with the advantage of carrying more passengers or freight (14). Additionally, increased heavy aircraft parking lots presents a rare opportunity to plan for long distance flights more frequently.

\section{A Huge Cargo Apron}

Today, freight transport has an important position globally so that the sector has to be supported by project-based investments and new incentives should be granted. Hence, Istanbul Airport was built in a way that, it is planned to meet the expectations of freight transport for Turkey even in the future. For this purpose, an enormous cargo apron has been built in the project which covers an area of 1.4 million square meters. This newly built unique cargo and logistics center allows over 30 wide body aircraft to be docked at the same time (14).

\section{Location Advantage}

Istanbul, a city of two continents, is located at a point so that it has the role of a bridge between Europe and Asia. The geographical location of the city strengthens its position in commercial and economic activities. Additionally, Istanbul that is also home to Istanbul Airport has unique historical and cultural advantages to attract more tourists, which means more flights. As a consequence, Istanbul Airport has a key role in long distance transportation as well as tourism activities. The airport has the potential to be used as a hub airport for many airlines. Specifically, traffic flying between far East and Europe can use the Airport as a transfer center where they can refuel and rest. 


\subsection{Weaknesses of Istanbul Airport}

\section{Weak transport network}

As stated above, the location of the airport is well-chosen and freight and passenger transport has great potential considering other airports in the world. However, the transport network between the airport and the city itself is not enough for optimum capacity utilization. Currently, the transportation between the city and the airport is done mostly by buses and other private units. A well-developed transport link is necessary to carry passengers and goods fast and easily. For this purpose, railway systems should be constructed to make transportation from all parts of the city efficient.

\section{Strong wind characteristics}

Located near the Black Sea, the airport is exposed to strong winds because of the characteristics of the area. Winds generally blow in the direction of North and South making the arrival/departure operations easy since the runways are located in the same direction. Nevertheless, the strong wind characteristics of the area, specifically strong cross winds, can sometimes jeopardize air traffic operations and increase the number of go-arounds.

\section{Longer Taxi Times for Some Cases}

Affected by several factors such as; runway configuration and congestion, taxiing between gates and runways are an indefinite part of air traffic management. Particularly in a major airport, the taxiing of an aircraft could take a considerable amount of time in actual flight hours.

Covering a huge land that includes 5 runways, aircraft movement area sometimes has an adverse effect on aircraft taxi times at Istanbul Airport. Distant runways are not easy to reach, particularly for southbound runway configurations.

\section{Optimization applications are needed}

The point that the modern aviation has reached and the importance of Istanbul Airport for Turkey has been explained above explicitly. The number of passengers and the amount of freight per year given on tables is an illustration of how big the sector is. While aviation keeps growing constantly in the world, there are things to be done to meet the requirements of this growth rate. Constructing new airports or adding up necessary physical instruments are sometimes hard to implement in aviation. Instead, revising prevailing procedures, making optimum use of the sources could be more efficient; time saving or less expensive. In this manner, optimization applications are quite common in modern aviation. Likewise, Istanbul Airport needs a variety of different optimization applications, specifically for aircraft taxi movements. For example: to save time and fuel, aircraft ground movements need to be optimized so that aircraft taxi times are shortened, long departure queues are eliminated. From another point of view; less fuel means less environmental damage, knowing that fuel consumption is directly correlated to environment. 


\subsection{Opportunities for Istanbul Airport}

\section{Major hub at the intersection of three Continents-Asia, Europe and Africa}

Istanbul Airport is located at the intersection of three continents; Asia, Europa and Africa. Once completed fully, it will offer flights to as many as 350 destinations because of its location advantage. When all the phases are completed, the Airport will have an advantage in being used as a major hub for many carriers.

Figure 6. Increased flight destinations from a major hub

\section{Increased flight frequencies for carriers}

Capacity extension is generally likely to increase market concentration. With an increase in demand, airlines will benefit from new routes and additional flights as long as the capacity allows them. Theoretically, Istanbul Airport holds an important position by numerical data compared to other competing airports and it offers many advantages for flight operations. Atatürk Airport, once the country's busiest airport, had a limited capacity so that airlines had problems with operational growth. The opening of the new airport has also opened up new advantages for airlines with the help of its huge size (16). The flag carrier of the country, Turkish Airlines, and other airlines are now able to increase flight frequencies at a considerable amount.

\section{Available new slots for new airlines}

The demand for air transportation has been growing all around the world. Many major airports are already congested, with demand far exceeding available air traffic capacity. This was one of the problems experienced before at Ataturk Airport. Because of an insufficient capacity, some airlines were not able to plan and execute flight operations to/from Ataturk Airport. However, Istanbul Airport offers available new slots to many carriers with the help of its infrastructure and increased air traffic capacity. 
As of April 2021, 73 different carriers have launched flight operations from/to Istanbul Airport including plans to in the near future. In recent years, carriers that did not fly to Ataturk Airport previously, have added Istanbul Airport to their destinations list such as; All Nippon Airways, IndiGo, and Juneyao Airlines (15).

\section{Increased passenger capacity}

Istanbul Airport is expected to host 200 million passengers per year when all the phases are completed. Currently, Hartsfield-Jackson Atlanta International Airport takes the lead with over 110 million passengers per year in 2019 according to International Council Airport (17). Considering this number Istanbul Airport will have almost twice the capacity of Atlanta International Airport, which also means a great contribution to the economy.

\section{Increased employment and economic growth}

The size of an airport is directly correlated to the economy. Providing employment opportunities and increasing revenues, a hub airport can foster sustainable economic growth. In this manner, new job opportunities have arisen; employment levels have increased with the capacity of the new airport. With direct and indirect employment at Istanbul Airport, thousands of people are provided with job opportunities that by far exceeds that of Ataturk Airport. Istanbul Airport is home to nearly 100 thousand employees and this number will go up to 225 thousand when it reaches full capacity with all phases operational. Clearly, those numbers are a demonstration of the airport's economic contribution to the country (18).

In addition, air transport is indispensable for tourism, and tourism has a strong linkage to the economic wealth of a country. With increased flight frequencies and additional destinations Istanbul Airport is of great importance in promoting global tourism and thus; the economy.

\section{Logistics capacity}

New cargo and logistics facilities included in the project is one of the core assets of Istanbul Airport. The size of the facilities, along with its location advantage, will play a key role for Istanbul Airport to become one of the important cargo hubs globally. Warehouses, logistic offices and all other small or large scale businesses will make a busy circulation if the capacity is used properly and effectively. The investments by national and international companies in air cargo will continuously increase revenues.

Figure-7 demonstrates the increase in freight transport (Cargo + Baggage + Postal Service) through 2010-2018 for Ataturk Airport. Clearly, the upper trend continued until the opening of Istanbul Airport (since then, those numbers have been shared by the two active airports). Now with ample place and more sophisticated facilities available at Istanbul Airport, those numbers tend to go up even more. 


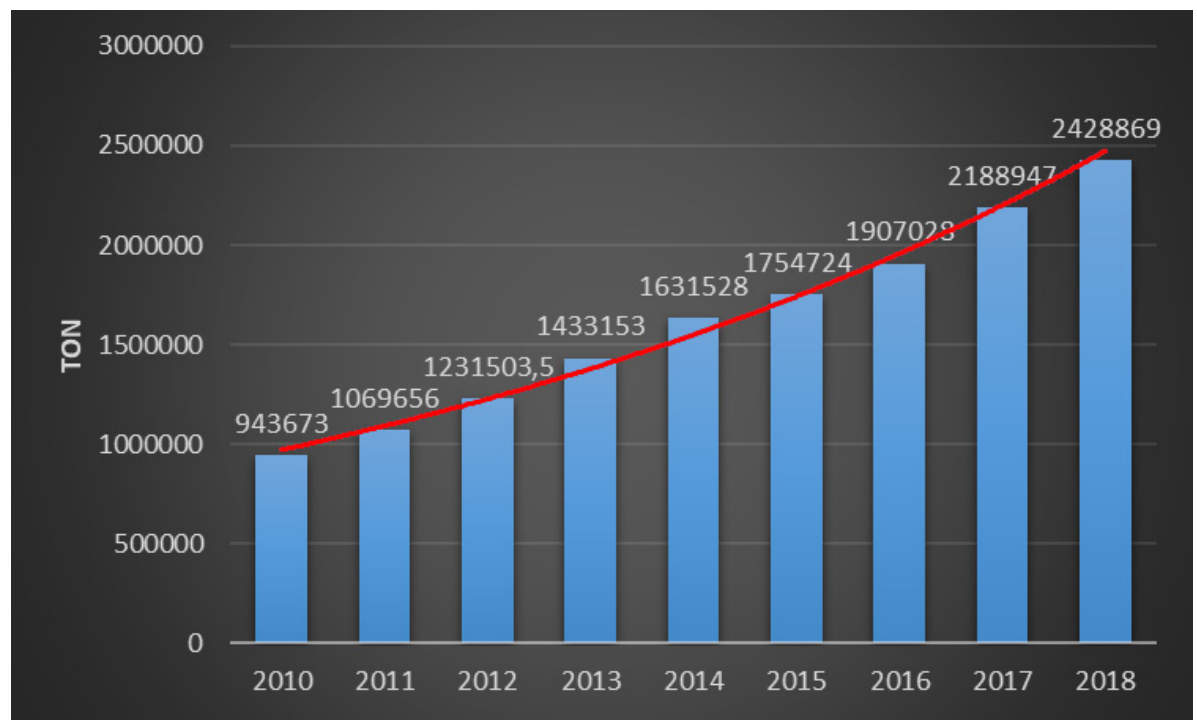

Figure 7. Freight Transport at Ataturk Airport through 2010-2018 (10).

\section{Efficiency and Delay Reduction}

We mentioned previously the kind of capacity problems at Ataturk Airport and how they are planned to be solved by the new airport. In simple terms, efficiency and reductions in delays; both for carriers and passengers are the main goals. Implementing new technologies and introducing agile optimization methods taxi time can be reduced and long departure queues can be eliminated which are quite common in hub airports.

\subsection{Threats for Istanbul Airport}

\section{Competitive Middle-East countries}

Even though Istanbul Airport has the above-mentioned advantages, there are other rival airport projects in the Middle East. Recently; some of the gulf countries, such as the United Arab Emirates, have declared projects that pose a strong threat to Istanbul Airport in the sector. For instance; transit traffic might find one those airports more efficient as a hub airport. For instance; airports in Dubai or Abu Dhabi, also might be an important time saving airport for transit traffic which fly from Asia to Europe or the reverse.

\section{Small scale airlines may not adapt to a new business environment}

As stated before, Istanbul Airport offers a lot for airlines in terms of capacity. However, small scale airlines are in danger of losing market share or even going bankrupt while larger scale airlines improve their flight frequencies. Hence; larger airlines might have a more advantageous position to grow while the small ones could risk their market share in this gigantic airport.

\section{The Flag Carrier may lose its market share for some destinations}

We have explained why Istanbul Airport offers a new increased flight capacity in the above -given statements. However, as for the flag carrier of Turkey, Turkish Airlines, this might be a problem for some of its destinations. With new carriers announcing flight 
operations to places where Turkish Airlines also fly, the flag carrier might lose its market share for those destinations.

\section{Migrating bird flyways}

Istanbul Airport was built in a location over which migrating bird flyways exist. Migratory birds use those flyways explicitly in certain times of a year. Unfortunately, airports are well known to be a threat for bird migration and their natural ecosystem. Moreover, birds flying through aircraft arrival and departure routes might hit an aircraft and/or be sucked in the engines endangering the aircraft's safety.

\section{Well-sophisticated management plans are required}

Laying out millions of square meters, covering long distances and employing thousands of people, Istanbul Airport requires well-sophisticated management plans that we can hardly encounter even in some countries. The integrity of this enormous business environment is well dependent on how well the management plans are made. Air traffic units, airport authorities, ground services and hundreds of other private units are all parts of an important chain. Therefore, sustainability as well as innovative approaches should be an important aspect of this complex system. This so called eco-system needs to be designed even to handle serious crises, either the reason is internal or external, such as the most current one; Covid-19 pandemic. Given this example, the dramatic decrease in demand could totally threaten the whole system causing hundreds of thousands of people to lose their jobs.

Table 6. SWOT analysis of Istanbul Airport

\begin{tabular}{|c|c|}
\hline STRENGTHS & WEAKNESSES \\
\hline $\begin{array}{ll}\checkmark & \text { Additional runway capacity } \\
\checkmark & \text { Point merge system } \\
\checkmark & \text { Increased aircraft capacity } \\
\checkmark & \text { The design to accommodate super-heavy aircraft } \\
\checkmark & \text { A Huge Cargo Apron } \\
\checkmark & \text { Location Advantage }\end{array}$ & $\begin{array}{ll}\checkmark & \text { Weak transport network } \\
\checkmark & \text { Strong wind characteristics } \\
\checkmark & \text { Longer taxi times for some cases } \\
\checkmark & \text { Optimization applications are needed }\end{array}$ \\
\hline OPPORTUNUTIES & THREATS \\
\hline $\begin{array}{ll}\checkmark & \text { Major hub at the intersection of three Continents-Asia, } \\
\text { Europe and Africa } \\
\checkmark & \text { Increased flight frequencies carriers } \\
\checkmark & \text { Available new slots for new airlines } \\
\checkmark & \text { Increased passenger capacity } \\
\checkmark & \text { Increased employment and economic growth } \\
\checkmark & \text { Logistics capacity } \\
\checkmark & \text { Efficiency and delay reduction }\end{array}$ & $\begin{array}{ll}\checkmark & \text { Competitive Middle-East countries } \\
\checkmark & \text { Small scale airlines may not adapt to new business } \\
\checkmark & \text { environment } \\
\checkmark & \text { The Flag Carrier may lose its market share for some } \\
& \text { destinations } \\
\checkmark & \text { Migrating bird flyways } \\
\checkmark & \text { Well-sophisticated management plans required }\end{array}$ \\
\hline
\end{tabular}

\section{Air Traffic Control Strategy for Istanbul Airport}

Air traffic control strategy is based on all of the sources available, passenger and cargo statistics, current market share and the expectations from the industry in the future. Considering the SWOT analysis above, it can be inferred that Istanbul Airport has a remarkable position in aviation not just for Turkey but also globally. These analyses give us a clear understanding of what should future air traffic control strategy be like. 
When we look at the information regarding Istanbul Airport, the most unique feature is the air traffic capacity and employment. Thus; making optimum use of the capacity should be of the utmost importance, because this will result in a value added to the economy of the country.

Integration of the airport and the city's transport network is quite important to carry passengers and cargo fast and comfortably. For this purpose, Istanbul Airport needs a much more developed transport network with the city itself and even with other neighboring cities. Ultimately, this will allow for uninterrupted transportation for business purposes and high commerce capacity. At this point, railway systems are efficient enough to serve as a main link. Constructing new railway systems, both for cargo and passenger transportation, after feasibility studies is needed along with ongoing railway projects.

The railway systems some of which are still ongoing projects should be designed, modernized and linked to the city so that it will easily and effectively serve to the final capacity of 200 million passengers per year. Additionally, airports that have a big cargo potential require goods to be carried in huge amounts and in a short period of time. It is a undeniable fact that railway systems are as important for cargo transportation as they are for passenger transportation. This is because these systems are economical, quicker and suitable for carrying heavy and huge amounts of goods even for long distances. For these reasons, railway transportation should also be applied to cargo transportation.

The advantageous position that Istanbul Airport has in terms of transit traffic has been explained above in depth. To retain this position, the number of facilities and the quality of services in and/or around the airport should be improved to better accommodate transit passengers. Attracted by quality services, the airport will, no doubt, be a preferable hub airport by many airlines along with its geographical advantage.

It will be easily seen that Istanbul Airport solves the capacity issue which was previously a problem for the limited area of Atatürk Airport. A limited capacity results in limited flight operations for carriers and time-delay for air traffic operations. As a result, air transportation won't be as cheap as we expect from airports such as Atatürk Airport. Hence, it is much more beneficial to provide cheaper air transportation from Istanbul Airport because of an improved capacity so that even new companies are now able to make flight operations. Providing a competitive business industry results in generalizing air transportation to the public as well as increasing companies' total income in many cases.

The expansion of Istanbul Airport is of another important subject. Prevailing runways were built according to the characteristics of the location and extend north to south. Adding a new runway parallel to the sea will make flight operations easier in the case of strong cross winds, and thus will reduce the number of go-arounds. Providing parallel runways extending east to west would be even more beneficial, one designated for arrival and another for departure operations. 


\section{Conclusion}

On this paper, a quick review of the history of aviation has been presented and the current status of the industry has been explained by numerical data. In light of the information given, it can be said that aviation shows a constant pattern of growth for Turkey as it does globally. Particularly, massive investments that were made recently put Turkish civil aviation in an excellent position. Turkey has had an enormous development potential in air transportation, specifically with the opening of Istanbul Airport. In the meantime, this potential requires additional investments to support the growth rate as we stated before. From this perspective, we provided solution methods that will support and increase the rate of development and that will make air transportation much more productive.

The analysis we provide in this paper mostly includes statements driven by Istanbul Airport's structural design. Technical approaches that will increase air traffic efficiency are not included on this study. For future work, we will introduce a variety of different technical subjects on air transportation such as; optimization applications and queuing theory, to analysis of air traffic efficiency.

Having done the above-given analysis, it can be concluded that Turkey has an advantageous position in civil aviation compared to other rival airports either with its socio-economic position or geographically. Making additional supportive investments for projects like Istanbul Airport will put Turkish aviation to the next level. Thus, taking a step forward in today's modernized civilizations, where they are not just looking to go up in the sky but also to pull ahead in the space race, will put the flag of aviation on top and will lead to more advanced developments.

Peer-review: Externally peer-reviewed.

Conflict of Interest: The authors have no conflict of interest to declare.

Grant Support: The authors declared that this study has received no financial support.

Acknowledgement: An earlier version of this paper was presented at the International Conference on Economics and Management EMAN 2017: Globalization Challenges, held in Ljubljana, Slovenia, March 30, 2017.

\section{References}

Çallioğlu T. Bulamık mantık kontrol tekniği kullanarak pist planlama için uçak tipine göre iniş önceliklendirme. Ankara: Gazi Üniversitesi; 2019.

Cangöz N. Yabancıların havayolu ulaşımını tercih etme nedenleri: türkiye’ye ait havayolu işletmeleri üzerine bir araştırma. Dergipark. Ocak 2018;11:196-213.

Aydin A. Metasezgisel yötemlerle uçak çizelgeleme problemi optimizasyonu. İstanbul: Marmara Üniversitesi; 2009.

Istanbul Ataturk Airport 2021 [Available from: https://en.wikipedia.org/wiki/Istanbul_Ataturk_Airport.

Özkan H. İnsansız hava araçlarının/drone'ların türk sivil havacılık hukukuna göre statüsü, unsurları ve ceza hukuku boyutuyla güncel sorunlar. TBB Dergisi. 2016;125.

Annual World Air Traffic Report - WATR 2019: ACI; 2019 [Available from: https://sci.aero/about-aci/ overview/aci-annual-report/.

Aircraft Movements: Airports Council International; 2021 [Available from: https://aci.aero/data-centre/ annual-traffic-data/aircraft-movements. 
Havayolu Yolcu Taşımacılığı Sektörü [Internet]. Türkiye İş Bankası. 2016.

DHMİ Hakkında: DHMI; 2020 [Available from: dhmi.gov.tr.

Havalimanları Karşılaştıramlı İstatistikleri: DHMI; 2020 [Available from: https://www.dhmi.gov.tr/Sayfalar/ Istatistikler.aspx.

İnşaat: İGA; 2020 [Available from: http://iga.phtools.net/istanbul-yeni-havalimani/insaat/.

Construction [Available from: http://iga.phtools.net/insaat-asamalar.html\#.

Dan IVANESCU CS, Constantine TAMVACLIS, Tarja KETTUNEN. Models of Air Traffic Merging Techniques: Evaluating Performance of Point Merge. 9th Aviation Technology, Integration and Operations Conference. Hilton Head, South Caroline: American Institute of Aeronautics and Astronautics (AIAA); 2009.

AIP Turkey 2021 [Available from: https://www.dhmi.gov.tr/sayfalar/aipturkey.aspx.

Istanbul Airport 2021 [Available from: https://tr.wikipedia.org/wiki/\%C4\%B0stanbul_Havaliman\%C4\%B1.

4. Ulusal Lojistik ve Tedarik Zinciri Kongresi Bildiriler Kitabı. Gümüşhane: Gümüşhane Üniversitesi İktisadi ve İdari Bilimler Fakültesi; 2015.

20 Airports for passenger traffic, cargo, and aircraft movement: ACI; 2020 [Available from: https://aci.aero/news/2020/02/19/aci-reveal-top-20-airports-for-passenger-traffic-cargo-and-aircraftmovements/.

İstanbul Havalimanında İlk Aşamada 16 Bin Kİşiye İstihdam İstanbu12020 [Available from: https://www.igairport.com/tr/basin-bültenleri/istanbul-havalimaninda-ilk-asamada-16-bin-kisiyeistihdam. 